\title{
Forced prolonged hospital stays as a manifestation of the dysfunction of the Polish long-term care system
}

\author{
JOANNA FURTAK-POBROTYN ${ }^{1, A-F}$, PIOTR POBROTYN ${ }^{2, A-F}$, ŁUKASZ RYPICZ ${ }^{3, B-F}$, \\ ROBERT SUSŁO ${ }^{4, D-F}$, JAROSŁAW DROBNIK ${ }^{4, A, ~ D, ~ I Z A B E L A ~ W I T C Z A K ~}{ }^{3, \text { B-F }}$ \\ 1 "Citodent" Dental Care Center, Oława, Poland \\ ${ }^{2}$ University Clinical Hospital in Wrocław, Poland \\ ${ }^{3}$ Economics and Quality in Health Care Unit, Public Health Department, Health Sciences Faculty, \\ Wrocław Medical University, Poland \\ ${ }^{4}$ Gerontology Unit, Public Health Department, Health Sciences Faculty, Wrocław Medical University, Poland
}

A - Study Design, B - Data Collection, C - Statistical Analysis, D - Data Interpretation, E - Manuscript Preparation, F - Literature Search, G - Funds Collection

Summary Background. Long-term care (LTC) services involve long-lasting continuous supervision, care, nursing, therapy, and rehabilitation of patients who do not qualify for acute medical care. Demand for LTC services is on the rise, because of the aging of society and increasing number of dependent young and middle-aged people.

Objectives. The aim of the study was to examine the dysfunction of LTC services in Poland, taking the phenomenon of prolonged hospitalization as an example.

Material and methods. We examined data on patients at the University Clinical Hospital in Wroclaw, Poland, who were waiting for transfer from hospital to LTC facilities in the years 2012-2017. The statistical threshold of significance was $p<0.05$.

Results. There were 1006 cases of hospital stays prolonged by waiting for transfer to LTC facilities; $77 \%$ of patients affected were 65 years or older. This age group saw a large increase in the total number of patients transferred from hospital to LTC facilities. Patients 65 years and older made up the majority of patients on transfer waiting lists, but their average waiting time was significantly shorter than that of younger patients (38.7 vs 69.6 days, respectively).

Conclusions. The demonstrated forced prolonged hospitalizations, which result from a lack of capacity on the part of LTC facilities to accept patients who have undergone hospital treatment, confirmed the dysfunction of the Polish LTC system. This results in a lack of adequate medical care continuity, increased total costs of medical care, and a shifting of expenses from the LTC facilities to the acute treatment facilities, which are most often hospitals.

Key words: long-term care, economics, hospital, patient care management, case management, hospitalization, delivery of health care.

Furtak-Pobrotyn J, Pobrotyn P, Rypicz $Ł$, Susło R, Drobnik J, Witczak I. Forced prolonged hospital stays as a manifestation of the dysfunction of the Polish long-term care system. Fam Med Prim Care Rev 2018; 20(3): 218-221, doi: https://doi.org/10.5114/fmpcr.2018.78254.

\section{Background}

Every human being is by nature entitled to benefit from the highest available level of physical and mental health care. The basic human right to health care consists of several complementary elements which entitle every person to benefit from the services, facilities, and conditions that are needed to achieve the highest available level of health perception, assuming that all of these needed elements are available in both physical and economic terms [1].

Demographic processes affect the demand for care and nursing services. The aging of society is commonly remarked on in this regard, but there is also an increasing problem of young and middle-aged people who are dependent on others because of congenital conditions, illness, trauma, or self-harm. From this point of view, long-term care (LTC) services are crucial; these involve long-lasting, sometimes continuous activities, such as supervision, care, nursing, therapy, and rehabilitation of patients who do not qualify to be treated in acute medical care facilities. Such activities require specialized staff capable of continuing on activities that may have been initiated during hospital treatment, and who are also able to introduce and sustain health promotion, often in close cooperation with primary care physicians [2].
According to the Polish national statistics office (Główny Urzqd Statystyczny, GUS) [3], the number of inpatient LTC facilities increased in the years 2010-2016 (Figure 1); however, the demand for these services still exceeds the supply and patients

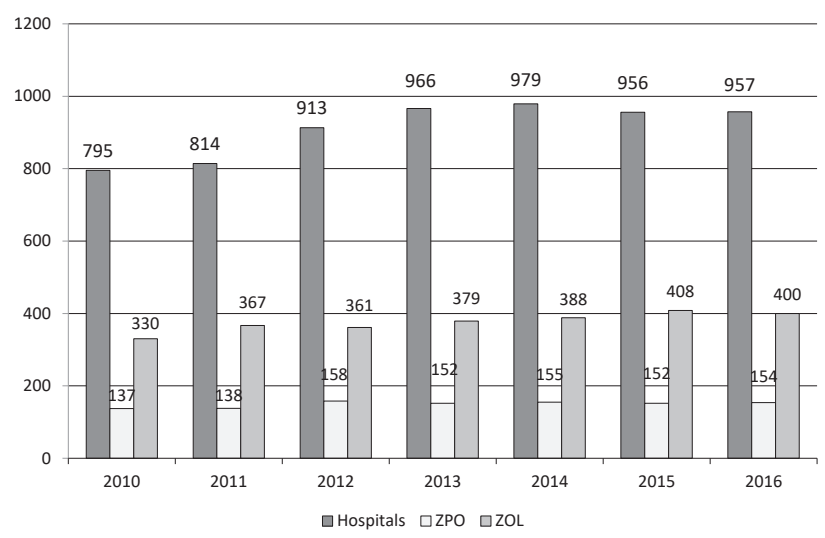

Figure 1. Number of hospitals, care and nursing facilities (ZPO), and care and treatment facilities (ZOL) in Poland in the years 2010-2016 [number of facilities]

Source of data: GUS [3]. 
usually have to wait for a place. In the Polish system, there are several LTC organizational types: inpatient facilities (hospices providing both care and treatment, called Zakłady Opiekuńczo-Lecznicze, ZOLs), facilities providing both nursing and care (Zakłady Pielęgnacyjno-Opiekuńcze, ZPOs); daytime facilities (specialized daytime palliative care); ambulatory facilities (palliative care ambulatories); and home care (community nurses and specialist teams). The most common of these are the inpatient care facilities [2]. Outside the health care system, there are also facilities that provide housing to socially incapable or otherwise dependent people (Domy Pomocy Społecznej, DPSs).

Since the thoroughgoing healthcare reform of 1997, funding of medical care in Poland has been neither adequate nor balanced [4], and care services have been slow to develop, not meeting increasing needs [5]. A significant number of patients who require these services therefore access them at their own expense at home, or else receive them from family members and other informal caregivers [6]. It is predicted that public spending in this area will rise dynamically, especially for care and nursing services, palliative, and hospice care. According to the Polish public health insurance fund (Narodowy Fundusz Zdrowia, NFZ), expenses for care and nursing services alone will have risen by over $30 \%$ by 2030 , reaching 1.5 billion PLN ( 0.35 billion EUR) [7].

Medical services are financed by the NFZ and, since 2005, the LTC services covered have been specified in great detail [8]. The patient is entitled to receive palliative care when there is a medical indication for it, when the patient needs it, and when the patient or that patient's caregiver consents to receive it. The units used in palliative care service calculations are patient- -days spent in inpatient hospice care facilities, palliative medicine wards, home hospices; and home hospices for children, plus number of home visits or consultations at home palliative medicine ambulatory facilities. The LTC services financed by the NFZ include basic services provided to patients with serious and chronic illnesses who do not require hospital care. These services are provided in palliative care wards, in chronic illness wards, at hospices, in home hospices, at palliative care ambulatories, at ZOLs, at ZPOs, at home as part of care for patients needing mechanical ventilation, and at home as long term nursing. However, the NFZ finances only ZOL and ZPO services for patients who score $0-40$ points on the Barthel scale. The types of services financed by the NFZ are enumerated in detail, along with their codes and units of account ("points") [9]. A higher cost in patient-days is assigned to medical services provided by home hospices, ZPOs, and ZOLs for children.

In the years 2008-2015, the NFZ made numerous changes in the details of contracting and financing, beginning to require that contracted LTC services be fulfilled in certain way. This included the introduction of a patient-day correction factor in case of care and nursing services provided to patients who scored $0-5$ points on the Barthel scale.

\section{Objectives}

The aim of this study was to examine the dysfunction of LTC services in Poland on the example of prolonged hospitalizations at the University Clinical Hospital in Wrocław, which resulted from the unavailability of post-hospitalization continuous care.

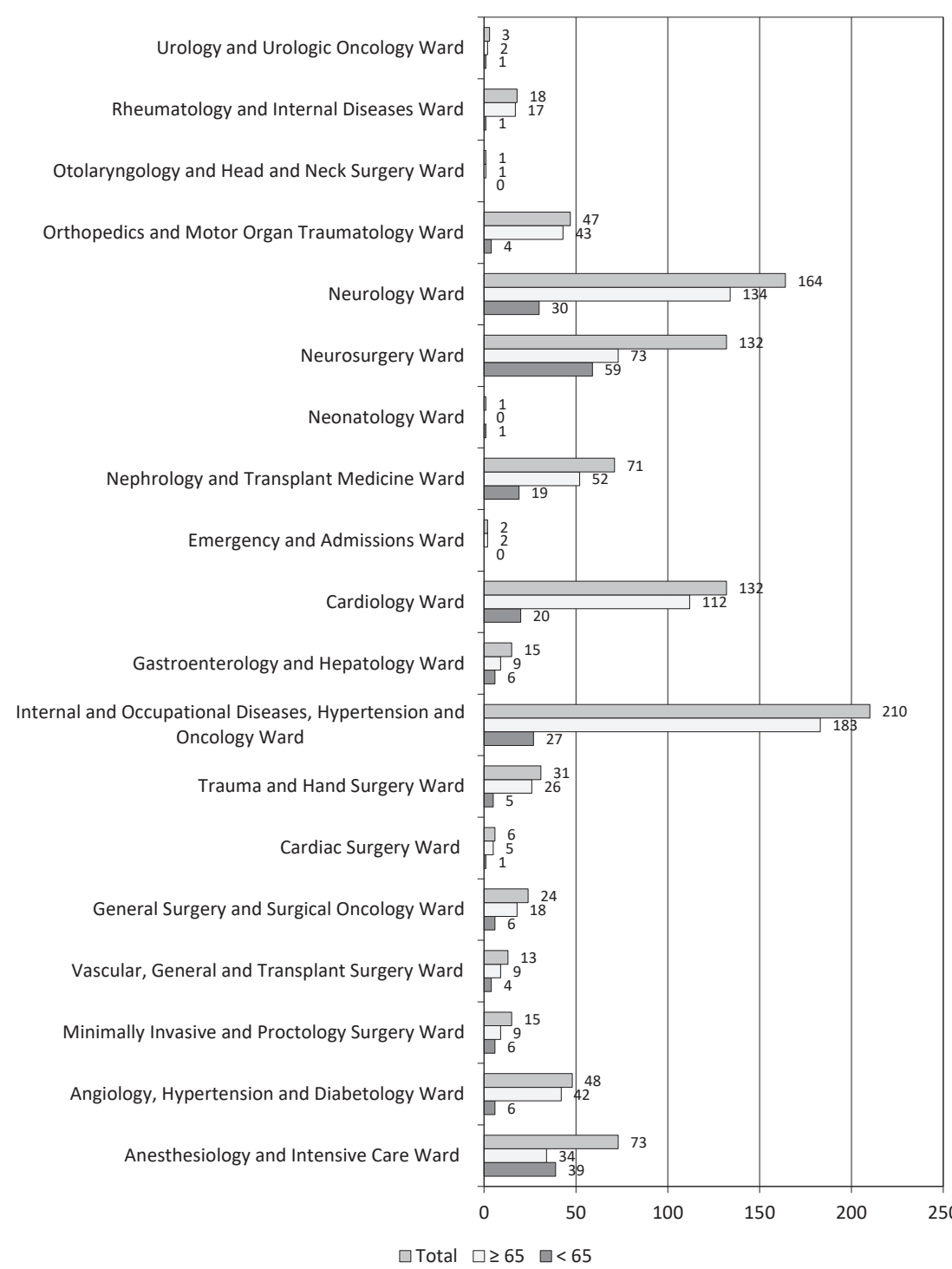

Figure 2. Number of cases of prolonged hospital stay in different wards of the University Clinical Hospital in Wroclaw, Poland in the years 2013-2017 caused by the need to wait for transfers to long-term care (LTC) facilities, by age: up to 65 years and 65 years and older [number of patients]

Source of data: University Clinical Hospital information systems. 


\section{Material and methods}

Data was collected on patients of the University Clinical Hospital who had to wait to be transferred from the hospital to the LTC facilities in the years 2012-2017. These data were analyzed using the statistical software Statistica 13.1 PL; the statistical threshold of significance was taken as $p<0.05$.

The study was approved by the Bioethics Committee of the Wroclaw Medical University, Poland (identification number of the opinion: KB.-608/2017).

\section{Results}

In the years 2012-2017, there were 1006 patients who were ready to be discharged from the study hospital, but whose hospital stay was prolonged due to the need to wait for places to become available in LTC facilities such as ZOLs, ZPOs, or DPSs. Of these patients, 771 (77\%) were 65 years of age or older; this age group also accounts for the large increase (about $50 \%$ in the years 2013-2015) observed in the total number of patients transferred from hospital to LTC facilities. The prolonged hospital stays were mostly reported by the neurology ward; the internal and occupational diseases, hypertension, and oncology ward; the cardiology ward; and the neurosurgery ward. The least number of delays were reported by the otolaryngology ward; the head and neck surgery ward; and the neonatology ward (Figure 2).
Our analysis reveals that patients aged 65 or older make up the majority of patients on the waiting lists, but their average waiting time in the years 2013-2017 was significantly shorter than that of younger patients (38.7 vs 69.6 days, respectively). The longest waiting times for transfer to LTC facilities were reported by the urology and urologic oncology ward; the orthopedics and locomotive traumatology ward; and the anesthesiology and intensive care ward; all of these involved patients under 65 years (Figure 3 ).

\section{Discussion}

The results of this study point to a lack of LTC services in Poland. This situation not only generates additional costs in the health care system - as hospital stay is much more expensive than any form of LTC - but also locks up precious hospital resources, rendering them unavailable to the patients who actually need them. Unnecessary prolonged hospitalizations also can initiate a vicious circle, as they can result in complications, including hospital infections, that would not have occurred in timely transfer of the patient had been possible. These complications require treatment in hospital, so affected patients is not transferred to LTC when it is their turn; instead, they undergo treatment in hospital and then join the transfer waiting list again. These prolonged hospital stays disrupt the continuity of treatment, as acute medical care facilities are not suited to or staffed for the purposes of providing LTC services.

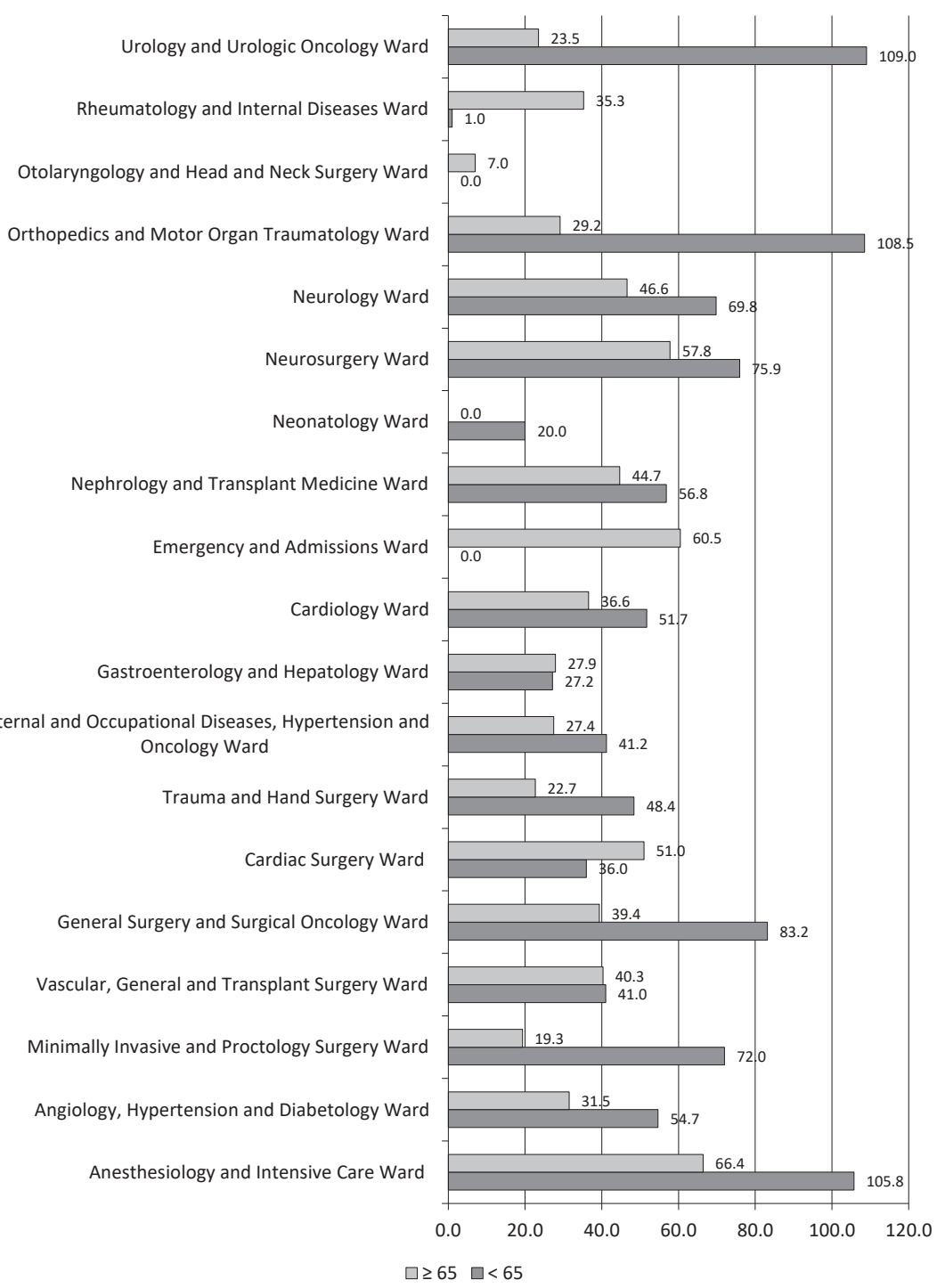

Figure 3. Average duration of prolonged hospital stay in different wards of the University Clinical Hospital in Wroclaw, Poland in the years 2013-2017 caused by the need to wait for transfers to long-term care (LTC) facilities, by age: up to 65 years and 65 years and older [days]

Source of data: University Clinical Hospital information system. 
Patients below the age of 65 showed a longer average hospital-LTC transfer waiting time than those over 65 , and this phenomenon needs to be investigated further. As many different predictions agree that Polish society will age rapidly in the decades to come, and since patients' need for care services increases steeply with age, it is clear that the deficit in LTC services will rapidly widen [10] so long as they remain both underfunded and underdeveloped in Poland [5]. According to a World Bank analysis, the total public expenditure on LTC in the years 2010-2013 in Poland were equal to about $0.8 \%$ of gross domestic product (GDP), one of the lowest such values in Europe [11]. The number of beds available in Polish facilities for long term care, whether medical or social, is too small; there is also a deficit of day care centers and other forms of support for dependent people at a time when, in other countries, fostering the deinstitutionalization of LTC, especially for the elderly, is becoming a priority $[12,13]$.

The Polish system of financing medical services does not make any significant differences in payment rates for LTC services, including palliative services and care and nursing that depend on the age of the beneficiaries. The payment received by the medical service provider depends primarily on the beneficiary's health state, which is estimated based on the level of illness advancement that made the beneficiary eligible to receive the given kind of service (assuming it is covered by public health insurance); however, no attention is paid to the general health and fitness status resulting from age-related processes of involution and degeneration, which gravely affect the level of care required and the costs associated with it.

\section{Conclusions}

By demonstrating the existence of the phenomenon of prolonged hospitalization - which results from the lack of capacity of LTC facilities to accept patients being transferred from hospital after treatment - this study has confirmed the insufficiency of LTC in Poland that has previously been described in the literature. This insufficiency results in a lack of adequate medical care continuity, an increased risk of in-hospital complications, elevated total costs of medical care, and the shifting of expenses from LTC facilities to acute treatment facilities, most often hospitals. It is to be expected that this problem will escalate in the years to come, as it currently mainly affects patients aged 65 years and older, and Polish society is aging rapidly. Until a systemic approach is found and successfully introduced to solve the problem of inadequate levels of LTC services in Poland, at least temporary relief could result from improving the coordination of different levels of medical and social care - including inpatient acute and chronic medical treatment facilities, specialist ambulatory medical services, and primary medical care.

Source of funding: This work was funded by the authors' resources. Conflict of interest: The authors declare no conflict of interests.

\section{References}

1. Mikołajczyk B. Międzynarodowa ochrona praw osób starszych. Warszawa: Wolters Kluwer; 2012: 236-237 (in Polish).

2. Cichońska D, Kostrzewa B, Budzisz R, et al. Opieka długoterminowa w Polsce - stan obecny, możliwości zmian - na podstawie badań w Zakładzie Pielęgnacyjno-Opiekuńczym w województwie mazowieckim. Przeds Zarz 2013; 10(3): 185-196 (in Polish).

3. Główny Urząd Statystyczny. Stacjonarna Opieka Zdrowotna [cited: 24.07.2018]. Available from URL: http://swaid.stat.gov.pl/ZdrowieOchronaZdrowia_dashboards/Raporty_predefiniowane/RAP_DBD_ZDR_3.aspx (in Polish).

4. Kollbek P, Lenkiewicz L, Drobnik J, et al. Analiza sposobu podziału środków Narodowego Funduszu Zdrowia i jego konsekwencji dla zaopatrzenia medycznego populacji dolnośląskiej. Probl Hig Epidemiol 2007; 1: 84-90 (in Polish).

5. Drobnik J, Susło R, Kurpas D, et al. Analiza systemu opieki nad osobami starszymi i ich potrzeb zdrowotnych na Dolnym Śląsku. Fam Med Prim Care Rev 2010; 12(2): 165-167 (in Polish).

6. Wróblewska I, Zborowska I, Dąbek A, et al. Health status, health behaviors, and the ability to perform everyday activities in Poles aged $\geq 65$ years staying in their home environment. Clin Interv Aging 2018; 13: 355-363, doi: https://dx.doi.org/10.2147/CIA.S152456 .

7. Fal A, Witczak I, Kuriata-Kościelniak E. Opieka geriatryczna w Polsce. Warszawa: Wydawnictwo CeDeWu; 2016.

8. Zarządzenie nr 11/2004 z dnia 13. października 2004 roku Prezesa Narodowego Funduszu Zdrowia w sprawie przyjęcia „Szczegółowych materiałów informacyjnych o przedmiocie postępowania w sprawie zawarcia umów o udzielanie świadczeń opieki zdrowotnej w rodzaju: opieka długoterminowa" [cited: 24.07.2018]. Available from URL: http://www.nfz.gov.pl/zarzadzenia-prezesa/zarzadzenia-prezesa-nfz/zarzadzenie-nr-112004,1313.html (in Polish).

9. Załącznik do zarządzenia Prezesa Narodowego Funduszu Zdrowia nr 11/2004 - „Szczegółowe materiały informacyjne o przedmiocie postępowania w sprawie zawarcia umów o udzielanie świadczeń opieki zdrowotnej w rodzaju: opieka długoterminowa” [cited: 24.07.2018]. Available from URL: http://www.nfz.gov.pl/download/gfx/nfz/pl/defaultaktualnosci/293/1313/1/z11z_2004.pdf (in Polish).

10. Ministerstwo Zdrowia. Stan faktyczny i perspektywy rozwoju opieki długoterminowej w Polsce, Warszawa 2012 [cited: 24.07.2018]. Available from URL: http://oipip.opole.pl/wp-content/uploads/2014/04/pod_strategia.pdf (in Polish).

11. Bank Światowy. Stan obecny i przyszłość opieki długoterminowej w starzejącej się Polsce - uwagi na potrzeby opracowania polityki długoterminowej, 2015 [cited: 24.07.2018]. Available from URL: http://www.niesamodzielnym.pl/uploads/Bank\%20\%C5\%9Awiatowy\%200pieka_dlugoterminowa.pdf (in Polish).

12. Gwarda-Żurańska J. Stan opieki długoterminowej w Polsce w latach 2010-2013. Acta Universtatis Lodziensis, Folia Oeconomica 2016; 1(318): 19-36 (in Polish).

13. Furmańska-Maruszak A, Wójtewicz A. Kierunki rozwoju usług opieki długoterminowej w Polsce. SOEP 2016; 9(4): 28-42.

Tables: 0

Figures: 3

References: 13

Received: 06.08.2018

Reviewed: 11.08.2018

Accepted: 13.08 .2018
Address for correspondence:

Robert Susło, MD, PhD

Zakład Gerontologii

Katedra Zdrowia Publicznego UM

ul. Bartla 5

51-618 Wrocław

Polska

Tel.: +48 71 347-90-29

E-mail: robertsuslo@gmail.com 